\title{
Biphasic buckwheat anaphylaxis: case report and systematic review
}

\author{
Ping-Hsien Yang, ${ }^{1}$ Shyh-Dar Shyur, ${ }^{2}$ Ming-Jer Liu, ${ }^{1}$ Hsin-Hui Chuang ${ }^{3}$
}

\begin{abstract}
Buckwheat anaphylaxis is commonly recognized in Europe and Asia, and there is only one case reported in Taiwan so far. Here, we report a case of biphasic buckwheat anaphylaxis in a 57 year-old male patient who lost consciousness twice in the same day after having buckwheat noodles. The serum test shows that Dermatophagoides pteronyssinus (Dp) immunoglobulin E (IgE) $(42.4 \mathrm{kU} / \mathrm{L})$ and buckwheat-specific IgE $(81.5 \mathrm{kU} / \mathrm{L})$ are unusually high. Although biphasic buckwheat anaphylaxis is rare, we should still be aware the second episode could be life-threatening and happen within a day after the exposure to the buckwheat antigen.
\end{abstract}

Keywords: buckwheat, anaphylaxis, biphasic, allergy, predictor

\section{From:}

${ }^{1}$ Department of allergy, immunology and rheumatology, Hsinchu Makay Memorial Hospital, No.690, Sec. 2, Guangfu Rd, East Dist, Hsinchu City, Taiwan

${ }^{2}$ Department of allergy, immunology and rheumatology, Taipei MacKay Memorial Children's Hospital, No. 92, Sec 2, Zhongshan N. Rd., Taipei City 10449, Taiwan

${ }^{3}$ Department of allergy, immunology and rheumatology, Taipei City Hospital Zhongxing Branch, No.87, Tongde Rd., Nangang Dist., Taipei City 111, Taiwan

\section{Introduction}

Buckwheat (Fagopyrum esculentum) and tartary buckwheat (Fagopyrum tartaricum) are widely used in traditional Japanese, Korean, and European diets. ${ }^{1}$ There is a growing consumption of health food in Taiwan, including buckwheat products. Besides, buckwheat is gluten-free and serves as a good alternative for celiac disease sufferers and other people intolerant of wheat flour. $^{2}$

Direct ingestion is not the only pathway to cause buckwheat anaphylaxis, which could also be caused by buckwheat contamination during food preparation. ${ }^{2}$ Therefore, the whole procedure of food preparation should be taken carefully for buckwheat-allergic patients. The incidence of buckwheat allergy is $0.22 \%$ in children. ${ }^{3}$ However, as a hidden antigen, the risk of buckwheat ingestion is usually underestimated.

Buckwheat is a rare allergen in Taiwan. The only case report is of a woman with asthma who had anaphylactic shock, generalized urticaria, and an acute exacerbation of asthma five minutes after ingesting buckwheat. ${ }^{4}$ To our knowledge, this is the first report of biphasic buckwheat anaphylactic shock in Taiwan.
Corresponding author:

Shyh-Dar Shyur

Taipei MacKay Memorial Hospital

No. 92, Sec 2, Zhingshan N. Rd., Taipei City 10449, Taiwan

Email: abc4540@gmail.com

\section{Case report}

A 57 year-old man had fainting, loss of consciousness and skin rash with wheal and flare developing 40 minutes after having buckwheat noodles. Immediately, he was brought to the emergency department by colleagues and was discharged two hours later after intramuscular (IM) injection of $0.5 \mathrm{mg}$ epinephrine and $10 \mathrm{mg}$ chlorphenamine. However, throat itching, generalized wheal and flare skin lesions, angioedema, fainting, and loss of consciousness were noted again within two hours of his return to his office. He was brought to the emergency department again right away. IM injection of 0.5 $\mathrm{mg}$ epinephrine and $10 \mathrm{mg}$ chlorphenamine were again given at the emergency room, and he was discharged after a 2-hour observation. He followed up in our outpatient department for further diagnosis and management one week later.

He has a past history of tongue numbness, dizziness, wheal and flare skin rash with pruritis, palpitations, and loss of consciousness that developed at the age of 54 within 30 minutes after ingesting buckwheat noodles. Besides, generalized wheal and flare skin rash developed at the age of 55 within 1 hour after ingesting whole grain bread (including buckwheat). There were no allergic symptoms (i.e., urticaria, itching throat, fainting, or angioedema) noted in his medical history after 
ingesting noodles or bread not containing buckwheat. The patient's history was negative for drug allergy.

His serum was tested for specific IgE to Dp, cat and dog danders, cockroach, and food allergens including egg white, milk, fish, wheat, and buckwheat (Table 1) with Pharmacia CAP system (Uppsala, Sweden), and only test results for Dp (42.4 kU/L, class 4) and buckwheat-specific $\operatorname{IgE}(81.5 \mathrm{kU} / \mathrm{L}$, class 5) were positive. Other blood test results were: hemoglobin $14 \mathrm{gm} / \mathrm{dL}$, hematocrit $40.9 \%$, white blood cell count $11,100 / \mu \mathrm{L}$, platelet count $351,000 / \mu \mathrm{L}$, blood sugar $97 \mathrm{mg} / \mathrm{dL}$, glycosylated hemoglobin (HbAlc) 5.8\%, and IgE $950 \mathrm{IU} / \mathrm{mL}$.

\section{Table 1. Specific IgE of the patient}

\begin{tabular}{|r|l|c|}
\hline \multicolumn{1}{|c|}{ Antigen } & Level (ku/L) & class \\
\hline D. pteronyssinus & 42.4 & 4 \\
\hline Cat dander & $<0.35$ & 0 \\
\hline Dog dander & $<0.35$ & 0 \\
\hline Cockroach & $<0.35$ & 0 \\
\hline Egg white & $<0.35$ & 0 \\
\hline Milk & $<0.35$ & 0 \\
\hline Fish & $<0.35$ & 0 \\
\hline Wheat & $<0.35$ & 0 \\
\hline Buckwheat & 81.5 & 5 \\
\hline
\end{tabular}

Class 0: $<0.35 \mathrm{kU} / \mathrm{L}$ Class 1: $0.35 \sim 0.7 \mathrm{kU} / \mathrm{L}$ Class 2: $0.7 \sim 3.5 \mathrm{kU} / \mathrm{L}$ Class 3: $3.5 \sim 17.5 \mathrm{kU} / \mathrm{L}$ Class 4: $17.5 \sim 50 \mathrm{kU} / \mathrm{L}$ Class 5: $50 \sim 100 \mathrm{kU} / \mathrm{L}$ Class 6: $>100 \mathrm{kU} / \mathrm{L}$

\section{Discussion}

IgE-mediated hypersensitivity to buckwheat is common in Korea, Japan, and some other Asian countries. ${ }^{4}$ It is also reported that the proportion of anaphylaxis was highest in the patients allergic to buckwheat in Korea. Therefore, the risk of buckwheat anaphylaxis should not be underestimated. We summarize (Table 2) the most common foods causing anaphylaxis, the prevalence of biphasic anaphylaxis, and the fatal cases in Asia from recent reports. ${ }^{5-14}$

Biphasic anaphylaxis refers to the second episode of anaphylaxis and has been reported to develop in up to $20 \%$ of reactions. ${ }^{15}$ There are no significant differences in baseline characteristics between patients with and without biphasic anaphylaxis, such as atopic diseases, triggers, precipitating factors (i.e., food, exercise, and medication), clinical manifestations, and treatments. ${ }^{6}$ However, it is known that the risk of biphasic anaphylaxis increases with multiple doses of epinephrine during the initial treatment. For instance, in one of the reports, pediatric patients received a dose of $0.01 \mathrm{mg} /$ $\mathrm{kg}$ (maximum dose $=0.5 \mathrm{mg}$ ). ${ }^{7}$ The risk also increases in pediatric patients taking a longer time to resolve from the first episode compared to the uniphasic reactors ${ }^{16}$ or having delayed administration of epinephrine. ${ }^{17}$ Additionally, we noted a delayed onset for the development of symptoms after the initial exposure to the antigen, ${ }^{18}$ and oral ingestion of antigen has been noted as a potential predisposing factor in two reports. ${ }^{18,20}$

Although double-blind placebo-controlled food challenge (DBPCFC) is the gold standard to confirm buckwheat allergy,

Table 2. summary of food anaphylaxis reports in Asian

\begin{tabular}{|c|c|c|c|c|c|c|c|}
\hline Authors & Country & $\begin{array}{l}\text { Numbers } \\
\text { of study } \\
\text { participants }\end{array}$ & population & $\begin{array}{l}\text { type of food } \\
\text { anaphylaxis }\end{array}$ & $\begin{array}{l}\text { Biphasic } \\
\text { anaphylaxis }\end{array}$ & Rate of death & $\begin{array}{l}\text { Time from } \\
\text { contact to onset }\end{array}$ \\
\hline $\begin{array}{l}\text { Wiparat } \\
\text { Manuyakorn } \\
\text { et al. }{ }^{5}\end{array}$ & Thailand & 160 & $\begin{array}{l}\text { Children } \\
\text { (aged } 3 \\
\text { months-18 years) }\end{array}$ & $\begin{array}{l}\text { Seafood }{ }^{*}(53.3 \%) \\
\text { Wheat* }^{*}(18.3 \%) \\
\text { Hen' egg }^{*}(11.7 \%) \\
\text { Cow's milk* }(1.7 \%)\end{array}$ & $8.7 \%$ & 0 & Not available \\
\hline $\begin{array}{l}\text { Ratchaya } \\
\text { Lertnawapan } \\
\text { et al. }{ }^{6}\end{array}$ & Thailand & 171 & $\begin{array}{l}\text { the median age: } \\
20.67 \text { years }\end{array}$ & $\begin{array}{l}\text { Seafood } \\
\text { Fried-insect } \\
\text { Fi }^{*}(23.7 \%)\end{array}$ & $6.3 \%$ & 0 & $\begin{array}{l}30 \text { minutes in } \\
\text { uniphasic group } \\
120 \text { minutes in } \\
\text { biphasic group }\end{array}$ \\
\hline $\begin{array}{l}\text { Naoyuki Inoue } \\
\text { et al. }{ }^{7}\end{array}$ & Japan & 61 & $\begin{array}{l}\text { Children } \\
\text { (aged } 2 \\
\text { months-14 years) }\end{array}$ & $\begin{array}{l}\operatorname{Egg}^{\star}(41.1 \%) \\
\operatorname{Milk}^{*}(21.4 \%) \\
\text { Wheat* }^{*}(14.3 \%)\end{array}$ & $3.3 \%$ & 0 & Not availables \\
\hline $\begin{array}{l}\text { Woei Kang Liew } \\
\text { et al. }{ }^{8}\end{array}$ & Singapore & 108 & $\begin{array}{l}\text { Children } \\
\text { (aged } 3 \text { years-11 } \\
\text { years) }\end{array}$ & $\begin{array}{l}\text { Peanut }(19 \%) \\
\text { Egg }(12 \%) \\
\text { Shellfish }(10 \%) \\
\text { Bird's nest }(10 \%)\end{array}$ & $3.6 \%$ & 0 & Not available \\
\hline $\begin{array}{l}\text { Kim M } \\
\text { et al. }{ }^{9}\end{array}$ & Korean & 29842 & $\begin{array}{l}\text { Children } \\
\text { (aged 6-16 years) }\end{array}$ & $\begin{array}{l}\text { Peanut }(0.08 \%) \\
\text { Cow's milk }(0.07 \%) \\
\text { Buckwheat }(0.06 \%) \\
\text { Hen's egg }(0.06 \%)\end{array}$ & $0.97 \%$ & 0 & Not available \\
\hline $\begin{array}{l}\text { Yang MS } \\
\text { et al. }{ }^{10}\end{array}$ & Korean & 138 & $\begin{array}{l}\text { no age limit } \\
\text { (only } 1 \text { patient }< \\
15 \text { years old) }\end{array}$ & $\begin{array}{l}\text { Wheat }(4.3 \%) \\
\text { Buckwheat }(4.3 \%) \\
\text { Seafood }(2.9 \%)\end{array}$ & $2.2 \%$ & $0.0001 \%$ & Not available \\
\hline $\begin{array}{l}\text { Vezir E } \\
\text { et al. }{ }^{11}\end{array}$ & Turkey & 96 & $\begin{array}{l}\text { Children } \\
\text { (mean age is } 7.4 \\
\text { years) }\end{array}$ & $\begin{array}{l}\text { Peanuts* and nuts }(30 \%) \\
\text { Cow's milk }^{*}(23.3 \%) \\
\text { Egg's white }{ }^{*}(20 \%)\end{array}$ & $5.2 \%$ & 0 & Not available \\
\hline
\end{tabular}


Table 2. (Continued) summary of food anaphylaxis reports in Asian

\begin{tabular}{|c|c|c|c|c|c|c|c|}
\hline Authors & Country & $\begin{array}{l}\text { Numbers } \\
\text { of study } \\
\text { participants }\end{array}$ & population & $\begin{array}{l}\text { type of food } \\
\text { anaphylaxis }\end{array}$ & $\begin{array}{l}\text { Biphasic } \\
\text { anaphylaxis }\end{array}$ & Rate of death & $\begin{array}{l}\text { Time from } \\
\text { contact to onset }\end{array}$ \\
\hline $\begin{array}{l}\text { Jiraponsananuruk } \\
\text { O } \\
\text { et al. }{ }^{12}\end{array}$ & Thailand & 101 & $\begin{array}{l}\text { no age limit } \\
\text { (aged } 2.8 \text { months } \\
\text { to } 81.3 \text { years) }\end{array}$ & $\begin{array}{l}\text { Seafood* }(45 \%) \\
\text { Wheat* }^{*}(8 \%) \\
\text { Milk* }^{*}(4 \%)\end{array}$ & $\begin{array}{l}7 \% \text { in pediatric } \\
\text { group } \\
2 \% \text { in adult } \\
\text { group }\end{array}$ & $0.00019 \%$ & $\begin{array}{l}30 \text { minutes }(50 \%) \text {, } \\
\text { more than } 60 \\
\text { minutes }(32 \%) \text {, } \\
30 \text { to } 60 \text { minutes } \\
(10 \%)\end{array}$ \\
\hline $\begin{array}{l}\text { Civelek E } \\
\text { et al. }{ }^{13}\end{array}$ & Turkey & 843 & $\begin{array}{l}\text { no age limit } \\
\text { (aged } 1-79 \text { years) }\end{array}$ & $\begin{array}{l}\text { Milk }(8 \%) \\
\text { Nut }(6 \%) \\
\text { Egg }(2.7 \%) \\
\text { Fish }(2.1 \%) \\
\text { Legume }(1.2 \%)\end{array}$ & $4.3 \%$ & 0 & Not available \\
\hline $\begin{array}{l}\text { Jeong KG } \\
\text { et al. }{ }^{14}\end{array}$ & Korean & 1353 & $\begin{array}{l}\text { Children } \\
\text { (aged }<18 \text { years) }\end{array}$ & 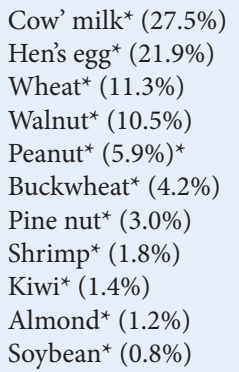 & Not available & Not available & Not available \\
\hline
\end{tabular}

* indicates that the statistics only include food allergens.

it is time-consuming and can be life-threatening. This risk can be avoided with measuring the food-specific IgE concentration in serum. Thus, the detection of crude buckwheat extract -specific IgE by ImmunoCAP (f11) (Phadia AB, Uppsala, Sweden) is widely used to diagnose buckwheat allergy. ${ }^{21}$

Sohn et al. concluded that a cutoff level of $1.26 \mathrm{kU} / \mathrm{L}$ of specific IgE for buckwheat was adequate for diagnosis in children with a strong clinical history. ${ }^{26}$ In this report, we utilized Pharmacia CAP to obtain the buckwheat-specific IgE concentration of $81.5 \mathrm{kU} / \mathrm{L}$ in serum, which is significantly higher than the cutoff value $(1.26 \mathrm{kU} / \mathrm{L})$ of the method mentioned above. The buckwheat-specific IgE concentration is extremely high, which is compatible with his severe allergic symptoms. We thought it was dangerous for the patient to try an oral food challenge. The specific IgE of wheat is significantly low $(<0.35 \mathrm{IU} / \mathrm{L}$, class 0$)$ in this patient. Besides, food containing wheat is common in Taiwan, and there are no related allergic symptoms found in the patient's history. Hence, we conclude that the patient is allergic to buckwheat without further examinations (e.g., the measurement of the major allergen in wheat, omega 5-gliadin).

Adrenaline (epinephrine) is essential to all patients experiencing anaphylaxis, which should be given by IM injection into the mid-outer thigh. The safety profile of IM adrenaline is excellent, although patients may experience transient pallor, palpitations, and headache. IM adrenaline $(1 \mathrm{mg} / \mathrm{mL})$ should be given at a dose of $0.01 \mathrm{~mL} / \mathrm{kg}$ of body weight to a maximum total dose of $0.5 \mathrm{~mL}$. When using adrenaline auto-injectors, patients weighing 7.5-25 kg should receive a $0.15 \mathrm{mg}$ dose with patients being moved to a $0.3 \mathrm{mg}$ dose at $25-30 \mathrm{~kg}$. The adrenaline dose can be repeated after at least a 5-minute interval. ${ }^{15}$
Oral (PO) or intravenous (IV) glucocorticosteroids are commonly used in anaphylaxis and are thought to possibly prevent protracted anaphylaxis symptoms, particularly in patients with concomitant asthma and biphasic reactions. ${ }^{9}$ The dose of hydrocortisone for adults and children depends on age: > 12 years and adults: $200 \mathrm{mg}$ IM or IV slowly; $>6$ to 12 years: $100 \mathrm{mg}$ IM or IV slowly; > 6 months to 6 years: $50 \mathrm{mg}$ IM or IV slowly; < 6 months: $25 \mathrm{mg}$ IM or IV slowly. ${ }^{23}$

With regard to monitoring and discharge arrangement, patients who present with respiratory compromise should be closely monitored for at least 6-8 hours, and patients who present with hypotension require close monitoring for at least $12-24$ hours. ${ }^{6}$ The education is important to the patients, including the of early recognition of anaphylactic symptoms and the avoidance of direct and indirect contacts with allergens, especially food allergens. Before discharge, the risk of future reactions should be assessed and an adrenaline auto-injector prescribed to those at risk of recurrence. Patients should be provided with a discharge advice sheet, including allergen avoidance measures (where possible) and instructions for when and how to use the adrenaline auto-injector. Referral to an allergy specialist is recommended to investigate possible triggers, assess and, where possible, to intervene to minimize the risk of further reactions, and ensure that patients and caregivers are optimally equipped and trained to manage any further reactions; and, if food is involved, referral to a registered dietitian. ${ }^{6}$

As buckwheat is becoming a popular health food in Taiwan, there is increasing prevalence of buckwheat anaphylaxis. When taking a history about exposure to allergens, buckwheat should be included. Besides, the correct management of this emergency can reduce the risk of biphasic anaphylaxis. 


\section{References}

1. Sammut D, Dennison P, Venter C, Kurukulaaratchy RJ. New disease Buckwheat allergy: a potential problem in 21st century Britain. BMJ Case Rep. 2011.

2. Heffler E, Guida G, Badiu I, Nebiolo F, Rolla G. Anaphylaxis after eating Italian pizza containing buckwheat as the hidden food allergen. J Investig Allergol Clin Immunol. 2007;17:261-3.

3. Takahashi Y, Ichikawa S, Aihara Y, Yokota S. Buckwheat allergy in 90,000 school children in Yokohama. Arerugi. 1998;47:26-33.

4. Wang TC, Shyur SD, Wen DC, Kao YH, Huang LH. Buckwheat Anaphylaxis: An Unusual Allergen in Taiwan. Asian Pac Allergy Immunol. 2006;24:167-70.

5. Manuyakorn W, Benjaponpitak S, Kamchaisatian W, Vilaiyuk S, Sasisakulporn C, Jotikasthira W. Pediatric anaphylaxis: triggers, clinical features, and treatment in a tertiary-care hospital. Asian Pac J Allergy Immunol. 2015;33:281-8.

6. Lertnawapan R, Maek-a-nantawat W. Anaphylaxis and biphasic phase in Thailand: 4-year observation. Allergol Int. 2011;60:283-9.

7. Inoue $\mathrm{N}$, Yamamoto A. Clinical evaluation of pediatric anaphylaxis and the necessity for multiple doses of epinephrine. Asia Pac Allergy. 2013;3:106-14.

8. Liew WK, Chiang WC, Goh AE, Lim HH, Chay OM, Chang S et al. Paediatric anaphylaxis in a Singaporean children cohort: changing food allergy triggers over time. Asia Pac Allergy. 2013;3:29-34.

9. Kim M, Lee JY, Jeon HY, Yang HK, Lee KJ. Prevalence of Immediate -Type Food Allergy in Korean Schoolchildren in 2015: A Nationwide, Population-based Study. Allergy Asthma Immunol Res. 2017;9:410-6.

10. Yang MS, Lee SH, Kim TW, Kwon JW, Lee SM. Epidemiologic and clinical features of anaphylaxis in Korea. Ann Allergy Asthma Immunol. 2008;100:31-6.

11. Vezir E, Erkoçoğlu M, Kaya A, Toyran M, Özcan C. Characteristics of anaphylaxis in children referred to a tertiary care center. Allergy Asthma Proc. 2013;34:239-46.
12. Jirapongsananuruk $\mathrm{O}$, Bunsawansong W, Piyaphanee N, Visitsunthorn $\mathrm{N}$, Thongngarm T. Features of patients with anaphylaxis admitted to a university hospital. Ann Allergy Asthma Immunol. 2007;98:157-62.

13. Civelek E, Erkoçoğlu M, Akan A, Özcan C, Kaya A. The Etiology and Clinical Features of Anaphylaxis in a developing country: A nationwide survey in Turkey. Asian Pac J Allergy Immunol. 2016;16.

14. Jeong KG, Kim JY, Ahn KM, Lee SY, Min TK. Age-based causes and clinical characteristics of immediate-type food allergy in Korean children. Allergy Asthma Immunol Res. 2017;9:423-30.

15. Muraro A, Roberts G, Worm M, Bilò MB, Brockow K. Anaphylaxis: guidelines from the European Academy of Allergy and Clinical Immunology. Allergy. 2014;69:1026-45.

16. Ellis AK, Day JH. Incidence and characteristics of biphasic anaphylaxis: a prospective evaluation of 103 patients. Ann Allergy Asthma Immunol. 2007; 98: 64-9.

17. Lee JM, Greenes DS. Biphasic anaphylactic reactions in pediatrics. Pediatrics. 2000; 106: 762-6.

18. Smit DV, Cameron PA, Rainer TH. Anaphylaxis presentations to an emergency department in Hong Kong: incidence and predictors of biphasic reactions. J Emerg Med. 2005;28:381-8.

19. Douglas DM, Sukenick E, Andrade WP, Brown JS. Biphasic systemic anaphylaxis: an inpatient and outpatient study. J Allergy Clin Immunol 1994;93:977-85.

20. Brady WJ, Jr., Luber S, Carter CT, Guertler A, Lindbeck G. Multiphasic anaphylaxis: an uncommon event in the emergency department. Acad Emerg Med. 1997;4:193-7.

21. Sampson HA. Utility of food-specific IgE concentrations in predicting symptomatic food allergy. J Allergy Clin Immunol 2001;107:891-6.

22. Sohn MH, Lee SY, Kim KE. Prediction of buckwheat allergy using specific IgE concentrations in children. Allergy. 2003;58:1308-10.

23. Soar J, Pumphrey R, Cant A, Clarke S, Corbett A. Emergency treatment of anaphylactic reactions--guidelines for healthcare providers. Resuscitation. 2008;77:157-69. 